\title{
THE SYLLIDAE (POLYCHAETOUS ANNELIDS) FROM JAPAN (VI) - DISTRIBUTION AND LITERATURE-
}

AUTHOR(S):

Imajima, Minoru

\section{CITATION:}

Imajima, Minoru. THE SYLLIDAE (POLYCHAETOUS ANNELIDS) FROM JAPAN (VI) -

DISTRIBUTION AND LITERATURE-. PUBLICATIONS OF THE SETO MARINE BIOLOGICAL LABORATORY 1967, 14(5): 351-368

ISSUE DATE:

1967-01-25

URL:

http://hdl.handle.net/2433/175453

RIGHT: 


\title{
THE SYLLIDAE (POLYCHAETOUS ANNELIDS) FROM JAPAN (VI)* DISTRIBUTION AND LITERATURE
}

\author{
MINORU IMAJIMA
}

National Science Museum, Japan

With 4 Maps and 4 Tables

\section{Distribution of Syllidae in the Uraga Strait at the entrance to Tokyo Bay}

Tokyo Bay is situated on the Pacific coast of the central part of the Japanese main island, Honshu. The bay is embraced by two peninsulas, the Miura Peninsula on the west, and the Boso Peninsula on the east. It is connected with the open ocean at the mouth of Sagami Bay by a narrow strip of water, the Uraga Strait. A submerged gorge, known as the Tokyo Submarine Canyon, cuts the shelf decply in the strait. However the canyon does not reach the main basin of Tokyo Bay and terminates rather abruptly midway in the strait, where it becomes narrower and shallower $(330-100 \mathrm{~m})$. The water in the Uraga Strait is much influenced by the coastal water of Tokyo Bay (Horikoshi, 1962).

Surveys were made by Dr. M. Horikoshi, of the Ocean Research Institute, University of Tokyo to provide information on the benthonic communities of Tokyo Bay. 127 stations were taken in this area. The bottom samples obtained by dredging were washed in a sieve of $1 \mathrm{~mm}$ standard mesh and then classified into several animal groups. The syllids treated here are a part of the polychaetes in this collection; their occurrences at respective stations are indicated in Map 2. Eleven species were represented as follows (some damaged specimens which could not be identified at the level of species were excluded from these data):
Autolytus (Autolytus) dentalius
Odontosyllis fulgurans japonica
Pionosyllis uraga
Haplosyllis spongicola
Syllis spongiphila
Syllis gracilis

*) Continued from Part 5 (XIV (4), pp. 253-294).

Publ. Seto Mar. Biol. Lab., XIV (5), 351-368, 1967. (Article 23) 
Langerhansia cornuta

Langerhansia japonica

Langerhansia rosea

Typosyllis aciculata orientalis

Typosyllis variegata

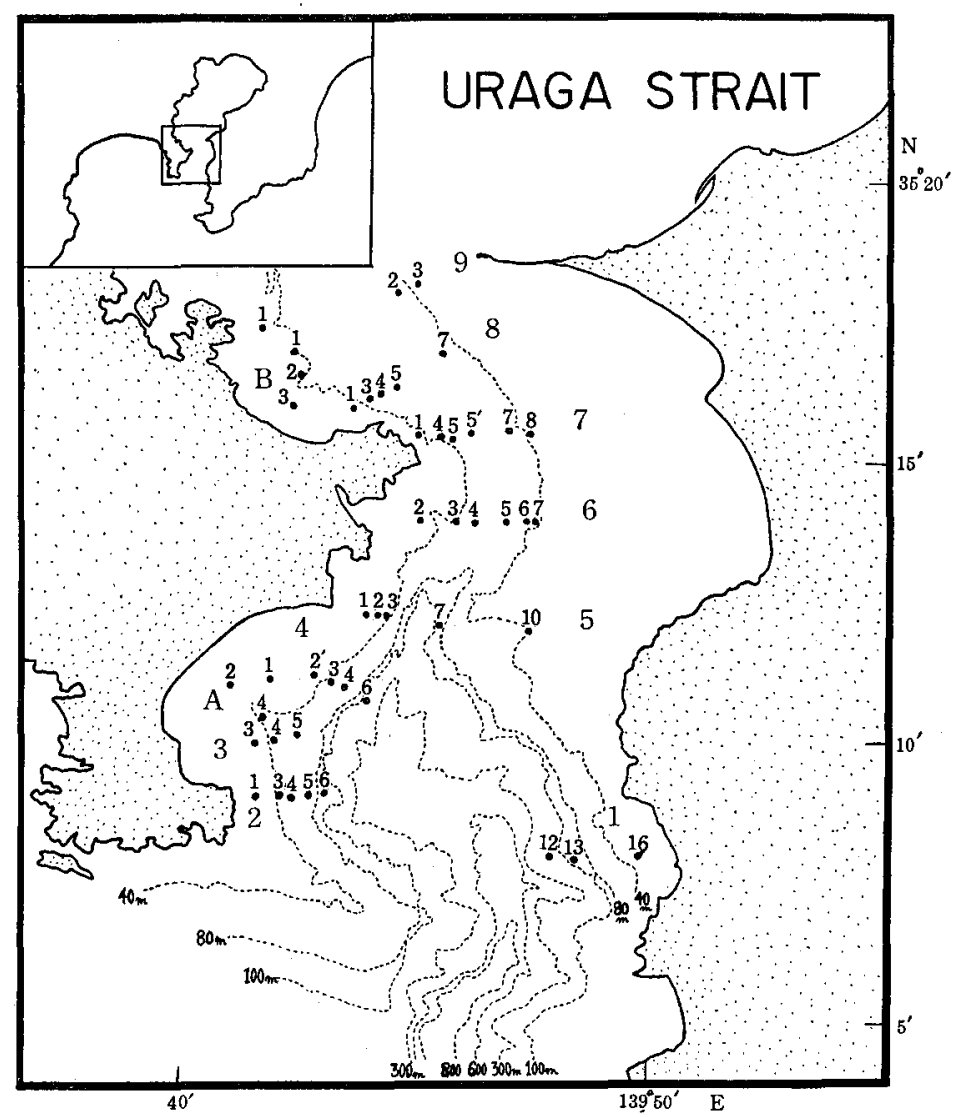

Map 2. Map of the Uraga Strait, showing the stations where syllids were collected.

Only one species was included in each of four genera: Autolytus, Odontosyllis, Pionosyllis and Haplosyllis (see above); they were distributed in 20 to $60 \mathrm{~m}$ depth. Eight of eleven species occurred at stations B-1,2,3, off Yokosuka City, in about $40 \mathrm{~m}$. The most dominant syllids in this area were Typosyllis variegata, Langerhansia cornuta and Typosyllis aciculata orientalis. They are widely distributed through depths to $200 \mathrm{~m}$.

Table II on page 354 and Map 3 indicate species names, their localities, and numbers of specimens. 


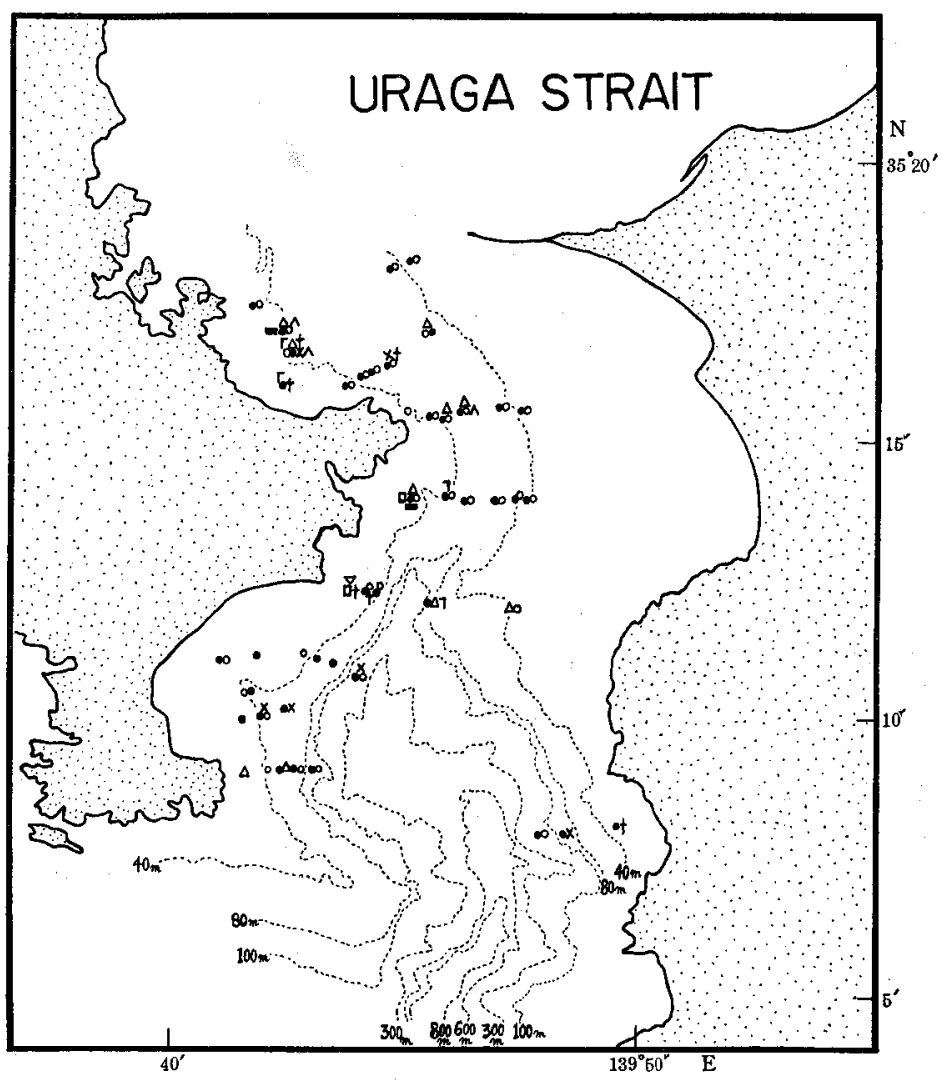

Map 3. Records of Syllids in the Uraga Strait.
$\nabla \cdots$ Autolytus (I.) dentalius
$+\cdots$ Odontosyllis fulgurans japonica
$\times$...Pionosyllis uraga
$\wedge$...Haplosyllis spongicola
$\neg \cdots$ Syllis spongiphila
$\lceil\ldots$ Syllis gracilis
O...Langerhansia cornuta
П... Langerhansia japonica
-...Langerhansia rosea
$\triangle \cdots$ Typosyllis aciculata orientalis
- $\cdots$ Typosyllis variegata 
Table II. Species and their occurring numbers at stations in the Uraga Strait.

\begin{tabular}{|c|c|}
\hline Species & Station and number of specimens \\
\hline Autolytus (A.) dentalius & St. $5-1,(1)$. \\
\hline Odontosyllis fulgurans japonica & St. B-2, (1); B-3, (2); 1-16, (1);5-1, (1);5-2, (1);8-5, (1). \\
\hline Pionosyllis uraga & St. B-2, (1);1-13, (2);3-4, (2);3-5, (2);4-6, (1);8-5, (1). \\
\hline Haplosyllis spongicola & St. B-1, (2); B-2, (8); 7-5', (4). \\
\hline Syllis spongiphila & St. $5-7,(1) ; 6-3,(2)$. \\
\hline Syllis gracilis & St. B-2, (3); B-3, (4). \\
\hline Langerhansia cornuta & $\begin{array}{l}\text { St. A-2, (2);A-4, (2); B-1, (3); B-2, (2);1-12, (1);2-3, (7);2-5, } \\
(4) ; 2-6,(2) ; 3-4,(1) ; 4-2^{\prime},(1) ; 4-6,(1) ; 5-2,(2) ; 5-3,(2) ; \\
5-10,(1) ; 6-2,(1) ; 6-3,(2) ; 6-4,(17) ; 6-5,(18) ; 6-6,(10) ; \\
6-7,(1) ; 7-1,(1) ; 7-4,(4) ; 7-5,(4) ; 7-5 ;(1) ; 7-7,(6) ; 7-8, \\
(3) ; 8-1,(1) ; 8-3,(30) ; 8-4,(7) ; 8-5,(3) ; 8-7,(4) ; 9-1,(4) ; \\
9-2,(7) ; 9-3,(1) .\end{array}$ \\
\hline Langerhansia japonica & St. $5-1,(1) ; 6-2,(1)$ \\
\hline Langerhansia rosea & St. B-1, (1);6-2, (1). \\
\hline Typosyllis aciculata orientalis & $\begin{array}{l}\text { St. B-1, (8); B-2, (11);2-1, (2); 2-4, (1);5-7, (1);5-10, (2); } \\
6-2,(1) ; 7-5,(2) ; 7-5^{\prime},(7) ; 8-7,(1)\end{array}$ \\
\hline Typosyllis variegata & $\begin{array}{l}\text { St. A-1, (3);A-2, (5);A-4, (2);B-1, (14);B-2, (36); B-3, (9); } \\
1-12,(2) ; 1-13,(2) ; 2-3,(5) ; 2-4,(5) ; 2-5,(6) ; 2-6,(2) ; 3-3, \\
(3) ; 3-4,(3) ; 3-5,(3) ; 4-3,(1) ; 4-4,(1) ; 4-6,(2) ; 5-2,(2) ; 5-3 \text {, } \\
(6) ; 5-7,(2) ; 6-2,(9) ; 6-3,(5) ; 6-4,(22) ; 6-5,(15) ; 6-6,(9) ; \\
6-7,(13) ; 7-4,(4) ; 7-5,(7) ; 7-5 \div,(19) ; 7-7,(8) ; 7-8,(3) ; 8-1, \\
(1) ; 8-3,(33) ; 8-4,(18) ; 8-5,(18) ; 8-7,(5) ; 9-1,(5) ; 9-2,(11) ; \\
9-3,(1) .\end{array}$ \\
\hline
\end{tabular}

\section{Distribution of Syllidae in the Ariake Sea}

The Ariake Sea is a large embayment located on the western coast of Kyushu Island. It is confined by Shimabara Peninsula on the western side and separated from the open sea on its south-western side by Amakusa Island. It is continued southerly to the Yatsushiro Sea where many islets are scattered. In 1957-58, several series of dredgings were made by the Hama Experimental Station of the Seikai Regional Fisheries Research Laboratory to provide the data on the benthonic communities of this sea. Many polychaetes were collected; among them only the syllids are treated in this report. Eleven species are represented; the following table shows their occurrences at respective stations indicated in Map 4. 
The surveys I to IV were made four times in two years; September, 1957...(I),

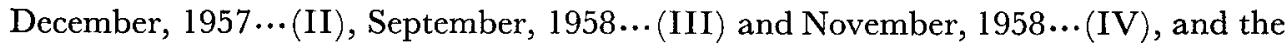
station number was repeatedly begun from 1 in each survey.

The following table indicates species names and their localities and number of specimens.

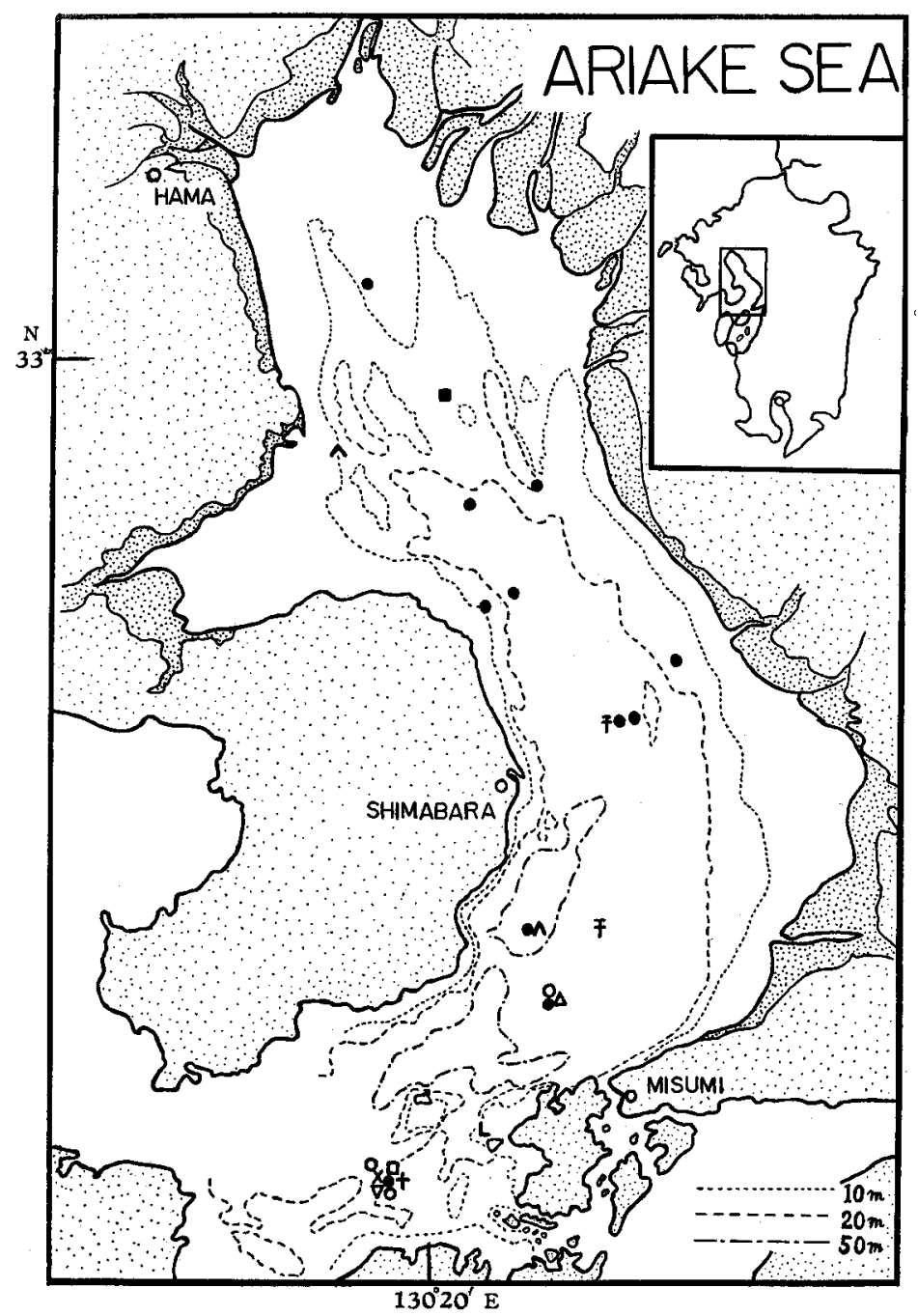

Map 4. Records of Syllids in the Ariake Sea.

$\mp$... Odontosyllis undecimdonta

$\nabla \cdots$ Syllis gracilis

$\triangle \cdots$ Langerhansia rosea

... Trypanosyllis (Trypanobia) asterobia

○...Typosyllis ehlersioides

$\times \cdots$ Typosyllis variegata
$\wedge$...Haplosyllis spongicola tentaculata

D...Langerhansia cornuta

L...Trypanosyllis (Trypanedenta) taeniaformis

$+\cdots$ Typosyllis aciculata orientalis

$\square$... Typosyllis fasciata 
Table III. Species and their occurring numbers at stations in the Ariake Sea.

\begin{tabular}{|c|c|}
\hline Species & Locality and number of specimens \\
\hline Odontosyllis undecimdonta & I-St. $18,(1) ; \operatorname{III}-37,(2)$. \\
\hline $\begin{array}{l}\text { Haplosyllis spongicola } \\
\text { tentaculata }\end{array}$ & $\mathrm{I}-24,(1) ; \mathrm{II}-57,(1)$ \\
\hline Syllis gracilis & III-58, (3). \\
\hline Langerhansia cornuta & III-9, (3). \\
\hline Langerhansia rosea & III-43, (1). \\
\hline $\begin{array}{l}\text { Trypanosyllis (Trypanedenta) } \\
\text { taeniaformis }\end{array}$ & II-61, (1). \\
\hline $\begin{array}{l}\text { Trypanosyllis (Trypanobia) } \\
\quad \text { asterobia }\end{array}$ & $\begin{array}{l}\text { I-18, (7); I-24, (9); II-22, (1); III-6, (1); III-14, (1); III-21, (1); } \\
\text { III-43, (2); III-50, (1); IV-15, (4); IV-19, (5); IV-20, (1). }\end{array}$ \\
\hline Typosyllis aciculata orientalis & III-50, (1). \\
\hline Typosyllis ehlersioides & $\mathrm{I}-31,(1) ; \mathrm{II}-70,(2) ; \mathrm{III}-43,(1)$ \\
\hline Typosyllis fasciata & III-50, (1). \\
\hline Typosyllis variegata & III-50, (1). \\
\hline
\end{tabular}

Haplosyllis spongicola tentaculata (MARION, 1879) was first described from France and has also been recorded from the Gulf of Naples by Cognetri (1954). This subspecies is new to Japan, and so far confined to the localities mentioned above.

Trypanosyllis (Trypanobia) asterobia OKADA (1933), first recorded at Misaki associated with an asteroid Luidia quinaria, was found at 11 stations; it is seemingly widely distributed in the Bay. At St. III-50 near the entrance of the Bay, the following four species were collected: Trypanosyllis (T. ) asterobia, Typosyllis variegata, Typosyllis aciculata orientalis and Syllis gracilis.

\section{Geographic Distribution}

Japan extends for nearly $20^{\circ}$ degrees of latitude, from $26^{\circ}$ to $45^{\circ}$ North. The Japanese Islands, situated 'chiefly in the temperate region, are influenced by two strong warm currents; the Kuroshio current from the tropical seas flows along the Pacific coast, and its branch, the Tsushima current, along the Japan Sea coast. The northern region, Hokkaido Island and northern Honshu, is affected by two different currents: a warm current in summer and a cold current in winter.

The warm Kuroshio current flows up along the east coast of Honshu a little beyond the Cape Inubozaki, then turns eastwards into the central part of the Pacific Ocean. In summer, the Tsushima current issues two or three branches just inside the entrance to the Japan Sea and near the western entrance to the Tsugaru Strait; main branches converge abruptly as they approach the Honshu coast and then the bulk of the water flows out to the Pacific Ocean through the strait. The water mass 
to the Pacific flows first eastwards and then turns to the south along the Sanriku coast; this is called the Tsugaru current (Nishimura, 1964).

The peripheral stream of the Tsushima current extends north along the west coast of Hokkaido and eventually penetrates into the Okhotsk Sea through Sōya Strait, riding on the Sōya current, to Abashiri (see Map 5).

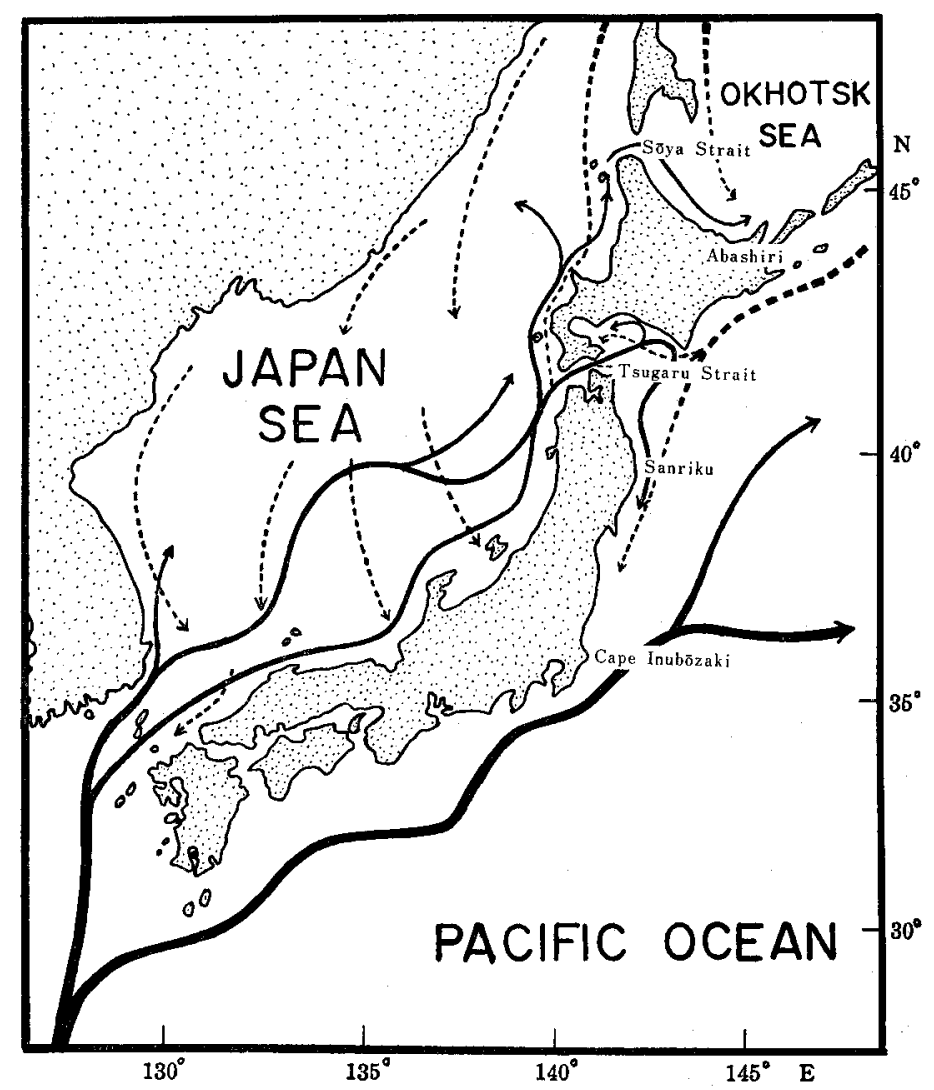

Map 5. Surface currents in winter and summer in the neighboring waters of Japan.

- surface currents of warm-water in summer
$\ldots .$. surface currents of cold-water in winter

The cold Oyashio current and the Liman current are very prominent in the midwinter; these currents wash all coasts of Hokkaido, northern Honshu on the Pacific coast and all the Japan Sea coasts of Honshu.

These currents around Japanese Islands, thus, bring forth the unique interesting biological circumstances where the northern and southern faunas are mixing with each other. 
The Japanese coasts have been divided into five areas. The first area includes Hokkaido Island, excluding its southwest coast; this is further subdivided into the Japan Sea coasts, the Okhotsk Sea and the Pacific coasts. The second area includes the coasts of the south-western end of Hokkaido and the northern end of Honshu comprising the Tsugaru Strait. The third area includes all of the coasts along the Japan Sea and Pacific Ocean, and further comprises the Seto Inland Sea; as the species from the Japan Sea coasts, only the specimens collected at Noto-ogi of the Noto Peninsula are represented in the present material. The fourth area comprises the Pacific coast of Shikoku, and the specimens from this area came from only Usa. The fifth area is represented by the southwestern coasts of Kyushu.

The syllids of Japan are here recorded with 86 species. The following breakdown is to illustrate the degree of endemism and some other distributional characteristics in Japan:

32 species and subspecies, or $37.2 \%$ of 86 species, have been previously recorded from Japan.

31 species and subspecies, or $36.0 \%$, are newly described.

21 species and subspecies, or $24.4 \%$, are newly added to the Japanese fauna.

2 species are not yet determined definitely.

The distribution of the Syllidae in the Japanese seas is influenced by those currents mentioned above, and resultantly the tropical and boreal species are differentiated. The list includes 16 species (or 18.6\% of the whole species) from the whole coasts of Hokkaido excluding the southwestern coast, and 45 (or 52.3\%) from the Tsugaru Strait, and 57 (or 66.2\%) from the Pacific coast of Honshu, and 28 (or 32.5\%) from the Seto Inland Sea, and 23 (or 26.7\%) from the coasts of the Japan Sea, and 21 (or 24.4\%) from the Pacific coast of Shikoku and 15 (or 17.4\%) from Kyushu.

Autolytus (Regulatus) vulgarius and Odontosyllis detecta commonly distributed along Honshu Island are not found on the coast of Hokkaido; the warm water species, Haplosyllis spongicola, is distributed south of Onagawa through southern Japan. Autolytus (R.) prismaticus, a boreal form, occurs only in Hokkaido and northern Honshu. The following eight species of Autolytus, A. (Autolytus) irregularis, A. (A.) japonensis, A. (A.) tsugarus, A. (A.) magnus, A. (Regulatus) nipponensis, $A .(R$.$) n. longicirratus, A .(R$. boreatus and $A$. $(R$.) alternata are found only in the Tsugaru Strait, from the intertidal zone to $360 \mathrm{~m}$.

The following four species of Autolytus, A. (A.) pentadentatus, A. (A.) spinoculatus, $A$. (R.) kiiensis and $A$. (R.) setoensis are collected only at Seto, Wakayama-prefecture.

The commoner species are: Sphaerosyllis hirsuta, Odontosyllis undecimdonta, Trypanosyllis (Trypanedenta) taeniaformis, Typosyllis nipponica, Typosyllis alternata, Typosyllis aciculata orientalis, Typosyllis adamanteus kurilensis, Typosyllis ehlersioides and Typosyllis variegata. 
Table IV. Distribution of syllids in Japan.

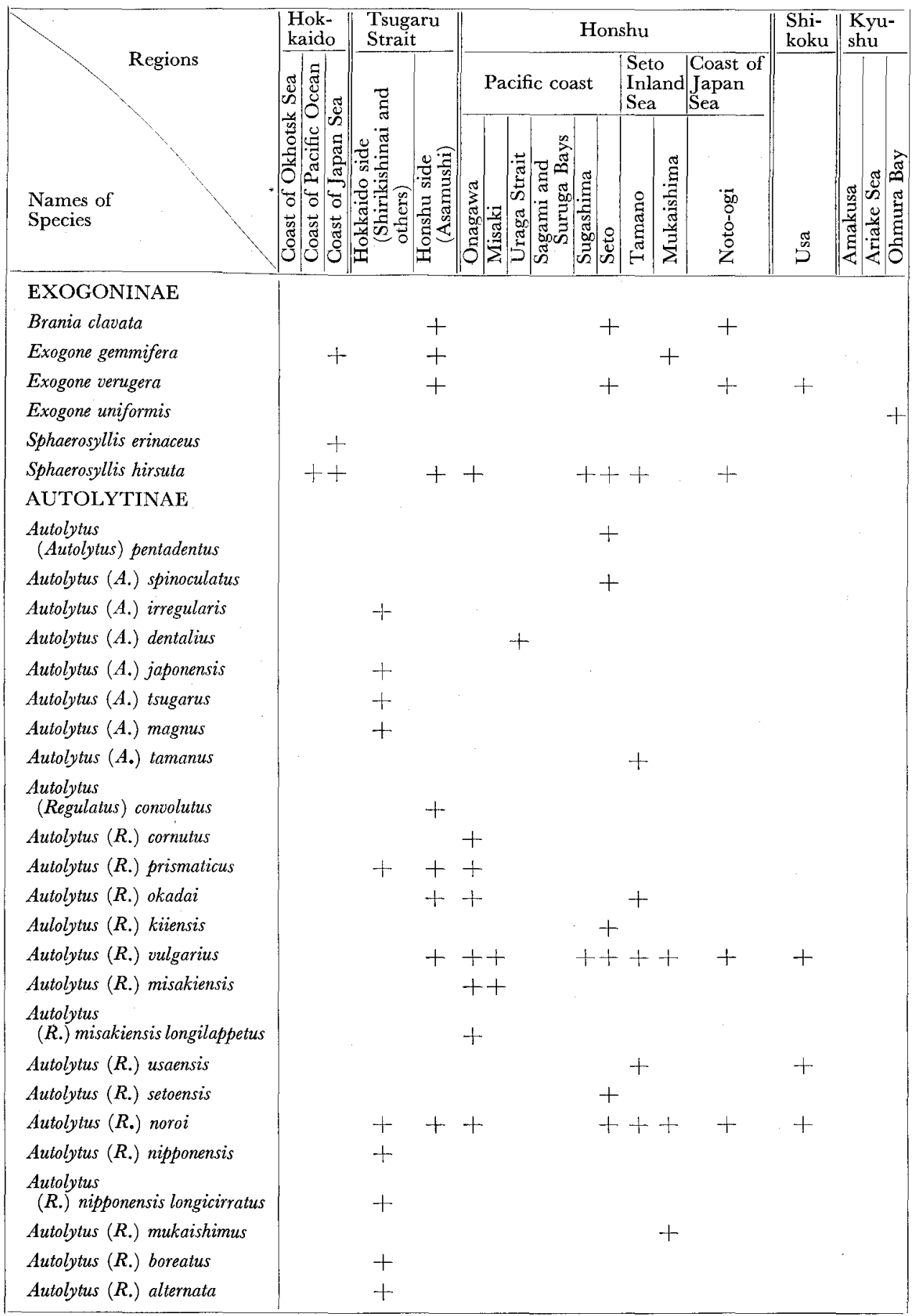


(Continued)

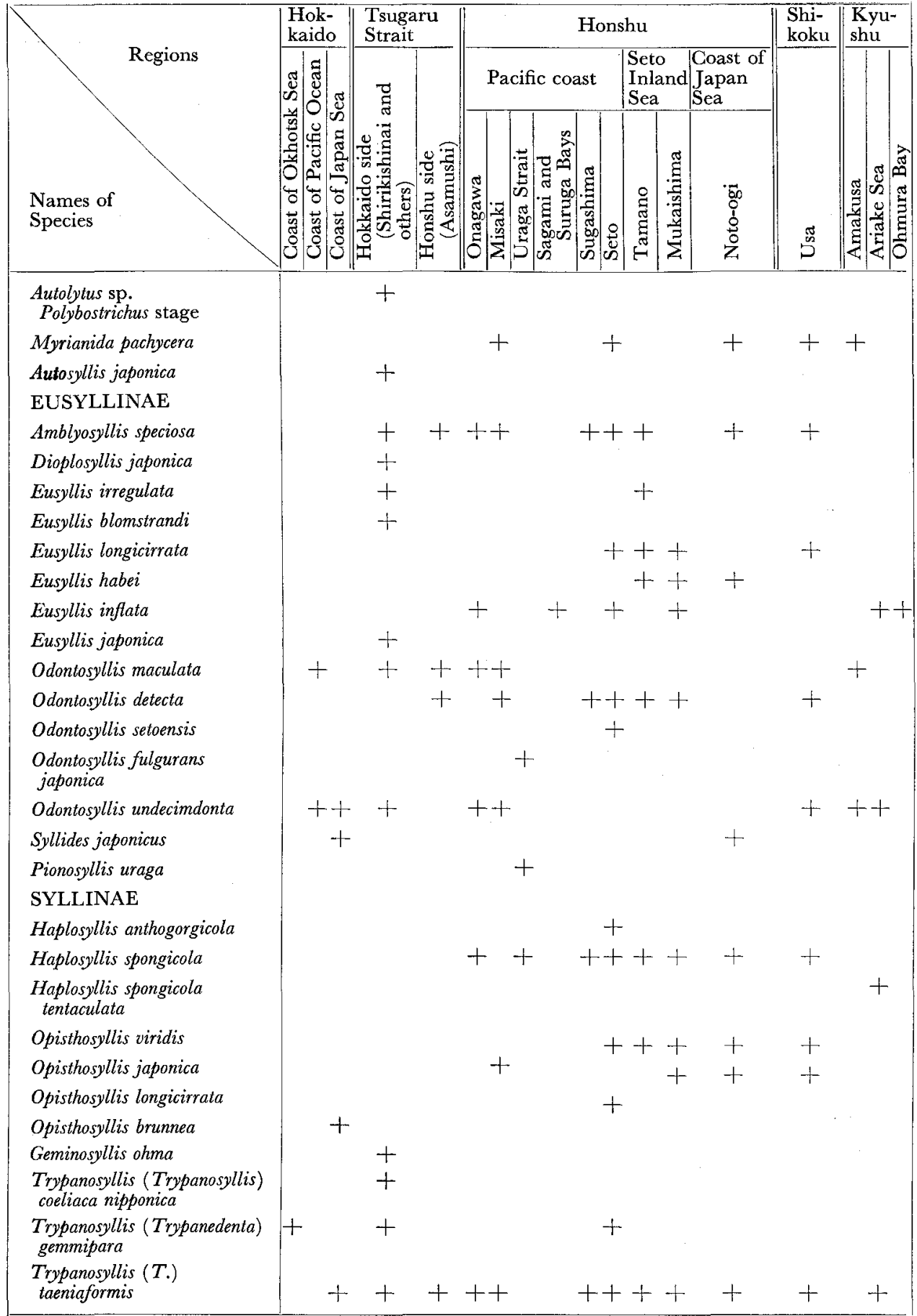


(Continued)

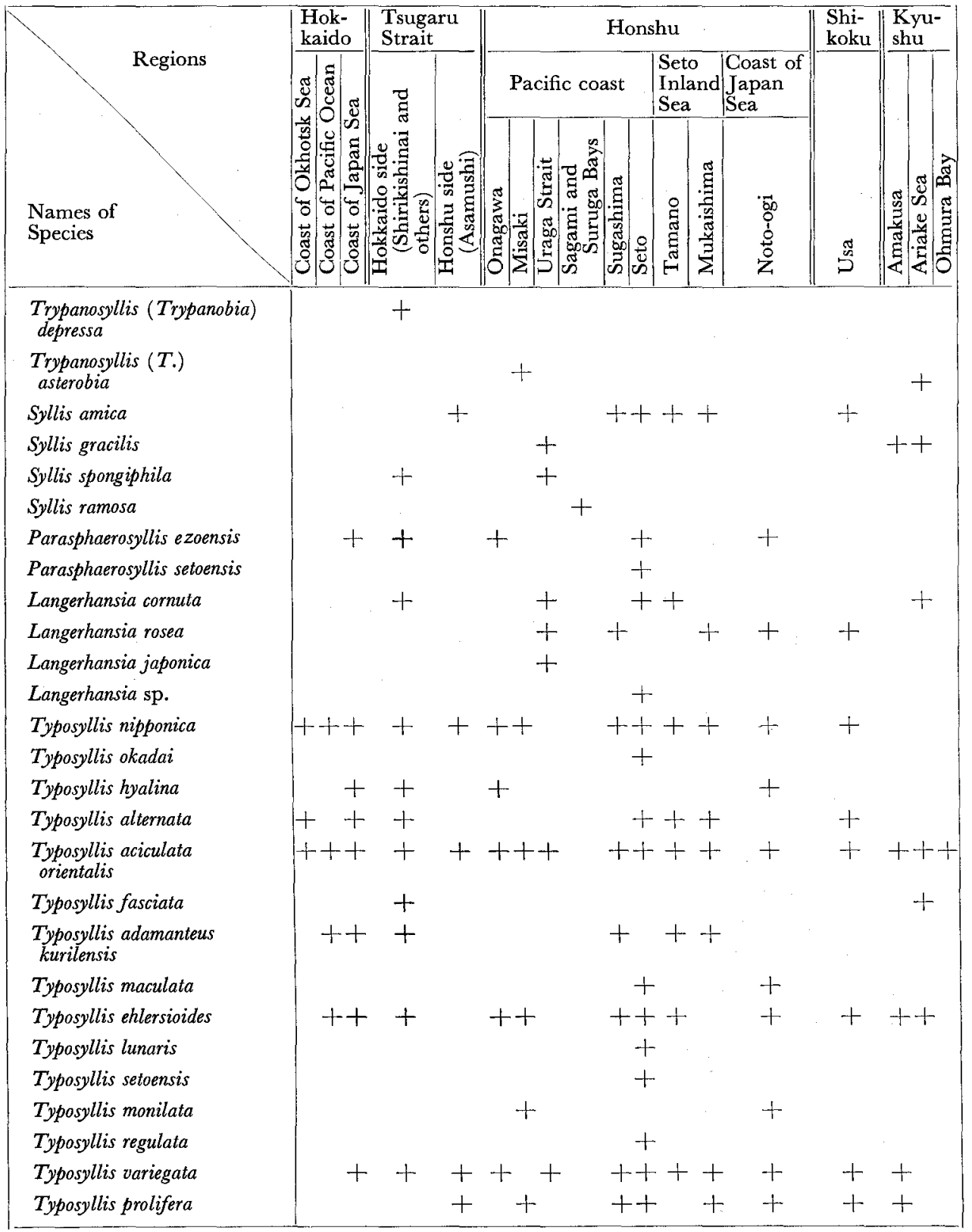


The Japanese syllids may be classified as follows according to their distributions:

46 species and subspecies, or $53.4 \%$ of the whole species, are known only from Japan.

8 species, or $9.3 \%$, are known also from the Yellow Sea.

10 species, or $11.6 \%$, are common to the Indo-Pacific areas.

17 species and subspecies, or $19.8 \%$, are known also from the Okhotsk, the Bering and the north Japan Seas.

14 species, or $16.2 \%$, are known also from the South and North Americas.

3 species, or $3.4 \%$, are known from the circumpolar area.

14 species and subspecies, or $16.2 \%$, are known also from the Mediterranean Sea.

22 species and subspecies, or 25:5\%, are known also from the Atlantic Ocean.

4 species, or $4.6 \%$, are cosmopolitan.

8 species, or $9.3 \%$, are known also from Australia.

4 species, or $4.6 \%$, are known also from Africa.

4 species, or $4.6 \%$, are known also from the Red Sea.

These data are shown in detail in the following table:

Table V. List of syllids in Japan, with distributional data.

\begin{tabular}{|c|c|c|c|c|c|c|c|c|c|c|c|c|}
\hline $\begin{array}{l}\text { Names of } \\
\text { Species }\end{array}$ & 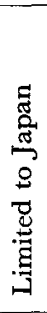 & 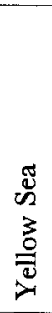 & 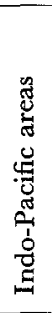 & 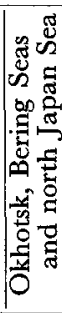 & 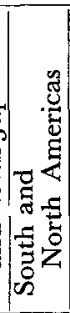 & 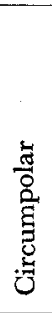 & 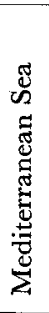 & 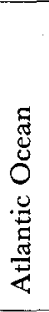 & 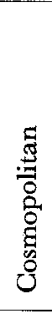 & 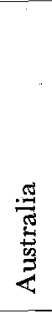 & 营 & $\begin{array}{l}8 \\
\& \\
8 \\
\mathscr{Z}\end{array}$ \\
\hline \multicolumn{13}{|l|}{ EXOGONINAE } \\
\hline Brania clavata & & + & & + & + & & + & + & + & & & \\
\hline Exogone gemmifera & & + & & + & + & + & + & + & + & & & \\
\hline Exogone verugera & & & & + & + & & + & + & + & + & + & \\
\hline Exogone uniformis & & & & & + & & & & & & & \\
\hline Sphaerosyllis erinaceus & & + & & + & & + & + & + & & & & \\
\hline Sphaerosyllis hirsuta & & & & + & + & & & & & & & \\
\hline AUTOLYTINAE & & & & & & & & & & & & \\
\hline Autolytus (Autolytus) pentadentus & + & & & & & & & & & & & \\
\hline Autolytus (A.) spinoculatus & + & & & & & & & & & & & \\
\hline Autolytus (A.) irregularis & + & & & & & & & & & & & \\
\hline Autolytus (A.) dentalius & & & & & & & & + & & & & \\
\hline Autolytus (A.) japonensis & + & & & & & & & & & & & \\
\hline Autolytus (A.) tsugarus & + & & & & & & & & & & & \\
\hline Autolytus (A.) magnus & & & & + & + & & & & & & & \\
\hline Autolytus $(A$.$) tamanus$ & + & & & & & & & & & & & \\
\hline Autolytus (Regulatus) convolutus & & & & & & & + & & & & & \\
\hline Autolytus (R.) cornutus & & & & & & & & + & & & & \\
\hline Autolytus (R.) prismaticus & & & & + & + & + & & + & & & & \\
\hline Autolytus (R.) okadai & & & & + & & & & & & & & \\
\hline Autolytus $(R$.$) kïensis$ & + & & & & & & & & & & & \\
\hline
\end{tabular}


(Continued)

\begin{tabular}{|c|c|c|c|c|c|c|c|c|c|c|c|c|}
\hline $\begin{array}{l}\text { Names of } \\
\text { Species }\end{array}$ & 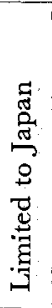 & 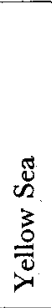 & 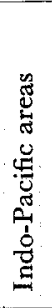 & 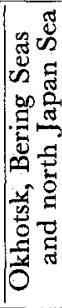 & 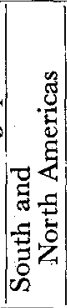 & 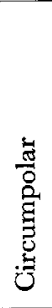 & 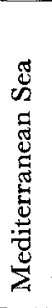 & 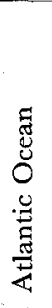 & 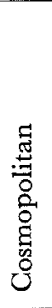 & 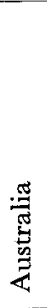 & 总 & $\begin{array}{l}\mathbb{J} \\
\text { D } \\
\ddot{Z} \\
\mathscr{4}\end{array}$ \\
\hline Autolytus $(R$.$) vulgarius$ & + & & & & & & & & & & & \\
\hline Autolytus (R.) misakiensis & + & & & & & & & & & & & \\
\hline $\begin{array}{l}\text { Autolytus }(R .) \text { misakiensis } \\
\text { longilappetus }\end{array}$ & + & & & & & & & & & & & \\
\hline Autolytus (R.) usaensis & + & & & & & & & & & & & \\
\hline Autolytus $(R$.$) setoensis$ & + & & & & & & & & & & & \\
\hline Autolytus (R.) noroi & + & & & & & & & & & & & \\
\hline Autolytus (R.) nipponensis & + & & & & & & & & & & & \\
\hline $\begin{array}{l}\text { Autolytus }(R .) \text { nipponensis } \\
\text { longicirratus }\end{array}$ & + & & & & & & & & & & & \\
\hline Autolytus (R.) mukaishimus & + & & & & & & & & & & & \\
\hline Autolyius $(R$.$) boreatus$ & + & & & & & & & & & & & \\
\hline Autolytus $(R$.$) alternata$ & + & & & & & & & & & & & \\
\hline Autolytus sp. Polybostrichus stage & $+?$ & & & & & & & & & & & \\
\hline Myrianida pachycera & & & & & & & & & & + & & \\
\hline Autosyllis japonica & + & & & & & & & & & & & \\
\hline EUSYLLINAE & & & & & & & & & & & & \\
\hline Amblyosyllis speciosa & + & & & & & & & & & & & \\
\hline Dioplosyllis japonica & + & & & & & & & & & & & \\
\hline Eusyllis irregulata & + & & & & & & & & & & & \\
\hline Eusyllis blomstrandi & & & & + & & & + & + & & & & \\
\hline Eusyllis longicirrata & + & & & & & & & & & & & \\
\hline Eusyllis habei & + & & & & & & & & & & & \\
\hline Eusyllis inflata & & + & & & & & & & & + & & \\
\hline Eusyllis japonica & + & & & & & & & & & & & \\
\hline Odontosyllis maculata & & + & & + & & & & & & & & \\
\hline Odontosyllis detecta & & & & & & & & & & + & & \\
\hline Odontosyllis setoensis & + & & & & & & & & & & & \\
\hline Odontosyllis fulgurans japonica & + & & & & & & & & & & & \\
\hline Odontosyllis undecimdonta & + & & & & & & & & & & & \\
\hline Syllides japonicus & + & & & & & & & & & & & \\
\hline Pionosyllis uraga & + & & & & & & & & & & & \\
\hline SYLLINAE & & & & & & & & & & & & \\
\hline Haplosyllis anthogorgicola & + & & & & & & & & & & & \\
\hline Haplosyllis spongicola & & & + & & + & & + & + & & & & \\
\hline Haplosyllis spongicola tentaculata & & & & & & & + & & & & & \\
\hline Opisthosyllis viridis & & & & & & & & + & & & & \\
\hline
\end{tabular}


(Continued)

\begin{tabular}{|c|c|c|c|c|c|c|c|c|c|c|c|c|}
\hline Region & 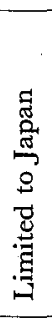 & 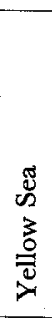 & 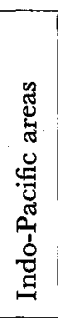 & 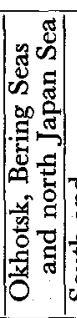 & 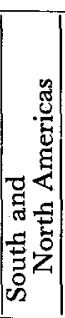 & 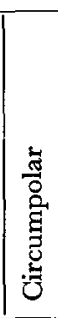 & 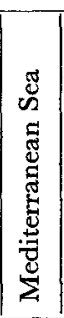 & 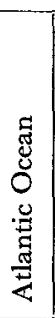 & 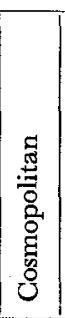 & 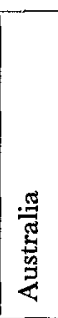 & 总 & $\mid \begin{array}{l}\mathscr{J} \\
\tilde{\omega} \\
\tilde{d} \\
\check{d}\end{array}$ \\
\hline Opisthosyllis japonica & + & & & & & & & & & & & \\
\hline Opisthosyllis longicirrata & & & + & & & & & & & & & \\
\hline Opisthosyllis brunnea & & & & & & & & + & & & & \\
\hline Geminosyllis ohma & + & & & & & & & & & & & \\
\hline $\begin{array}{l}\text { Trypanosyllis (Trypanosyllis) } \\
\text { coeliaca nipponica }\end{array}$ & + & & & & & & & & & & & \\
\hline $\begin{array}{l}\text { Trypanosyllis (Trypanedenta) } \\
\text { gemmipara }\end{array}$ & & & + & + & + & & & + & & & & \\
\hline Trypanosyllis $(T$.$) taeniaformis$ & & & + & & & & & & & + & & \\
\hline Trypanosyllis (Trypanobia) depressa & & & & & & & & & & + & & \\
\hline Trypanosyllis (T.) asterobia & + & & & & & & & & & & & \\
\hline Syllis amica & & & & & & & + & + & & & & \\
\hline Syllis gracilis & & & + & & + & & + & + & & & + & \\
\hline Syllis spongiphila & & & & + & + & & & + & & & & \\
\hline Syllis ramosa & & & + & & & & & & & & & \\
\hline Parasphaerosyllis ezoensis & + & & & & & & & & & & & \\
\hline Parasphaerosyllis setoensis & + & & & & & & & & & & & \\
\hline Langerhansia cornuta & & + & + & & & & + & + & & & & \\
\hline Langerhansia rosea & & & & & & & & + & & & & \\
\hline Langerhansia japonica & + & & & & & & & & & & & \\
\hline Langerhansia sp. & + & & & & & & & & & & & \\
\hline Typosyllis nipponica & + & & & & & & & & & & & \\
\hline Typosyllis okadai & & & + & & & & & & & & & \\
\hline Typosyllis hyalina & & & & & + & & + & + & & & & \\
\hline Typosyllis alternata & & & & + & + & & & & & & & \\
\hline Typosyllis aciculata orientalis & & & & & & & & + & & & & \\
\hline Typosyllis fasciata & & + & & + & & & & + & & & & \\
\hline Typosyllis adamanteus kurilensis & & & & + & & & & & & & & \\
\hline Typosyllis maculata & + & & & & & & & & & & & \\
\hline Typosyllis ehlersioides & & & & + & & & & & & & & \\
\hline Typosyllis lunaris & + & & & & & & & & & & & \\
\hline Typosyllis setoensis & + & & & & & & & & & & & \\
\hline Typosyllis monilata & + & & & & & & & & & & & \\
\hline Typosyllis regulata & & & & & & & & & & + & & \\
\hline Typosyllis variegata & & + & + & + & + & & + & + & + & + & + & \\
\hline Typosyllis prolifera & & & + & & & & + & + & & & & \\
\hline
\end{tabular}




\section{Literature}

Annenkova, N.P. 1937. Fauna Polychaeta severnoi chastĩ Iâponskogo Moriâ. Akad. Nauk SSSR, Issledovaniiâ morei SSSR, 23: 139-216, pls. 1-5, figs. 1-12.

Augener, H. 1913. Polychaeta I. Errantia. In Michaelsen und Hartmeyer, Die Fauna SudwestAustraliens. Ergeb. der Hamburger Südwest-Australiens Forschungsreise 1905, 4: 65-304, 2 pls., 42 figs.

Berkeley, E. 1923. Polychaetous Annelids from the Nanaimo District. Part I. Syllidae to Sigalionidae. Contribs. Canad. Biol., n. s. 1: 203-218, 1 pl.

Berkeley, E. and C. Berkeley 1938. Notes on Polychaeta from the Coast of Western Canada. II. Syllidae. Ann. Mag. Nat. Hist., (11) 1: 33-49, figs. 1-12.

1945. Notes on Polychaeta from the Coast of Western Canada. III. Further Notes on Syllidae and some Observations on other Polychaeta Errantia. Ann. Mag. Nat. Hist., (11) 12: 316-35, figs. 1-6.

1948. Annelida. Polychaeta Errantia. Canad. Pac. Fauna, 9b (1): 1-100, 160 figs.

Chamberlin, R.V. 1919. The Annelida Polychaeta. Mem. Mus. Comp. Zool. Harvard Univ., 48: $1-514$, pls. $1-80$.

Chlebovitsch, V.V. 1959. Species of Polychaeta worms from the Kuril Islands, which are new or recorded for the first time in the USSR fauna. (In Russian with English summary). Zool. Zhurnal, $38(2)$ : 167-181, figs. 1-10.

1961. Mnogoshchetinkovye chervi (Polychaeta) litorali kuril'skikh Ostrovov. Issledovaniia dal'nevostochnykh morei SSSR, 7: 151-260, figs. 1-14.

Claparède, E. 1863. Beobachtungen über Anatomie und Entwicklungsgeschichte wirbelloser Thiere an der Küste von Normandie angestellt. Leipzig. vii: 120 pp., 18 pls.

1864. Glanures Zootomiques parmi les Annélides de Port-Vendres (Pyrénées Orientales). Mém. Soc. de Phys. et Hist. Nat. Genève, 17: 463-600, 8 pls.

1868. Les annélides chétopodes du Golfe de Naples. Ibid. 19 (2): 313-584, 16 pls.

Cognetri, G. 1953. Osservazioni sulla biologia riproduttiva di una nuova specie di Autolytus del golfo di Napoli. Arch. Zool. Ital., 38: 323-332, 1 pl., 7 figs.

-_1954. Ricerche sui Sillidi del Golfo di Napoli. Pubbl. Staz. Zool. Napoli, 26 (1): 1-11, 5 figs.

1957. I Syllidi del golfo di Napoli. Ibid., 30: 1-100, 2 pls., 18 figs.

1961. Les Syllidiens des côtes de Bretagne. Cahiers de Biol. Mar., 2: 291-312.

DAy, J.H. 1953. The Polychaet Fauna of South Africa. Part 2. Errant Species from Cape Shores and Estuaries. Ann. Natal Mus., 12: 397-441, figs. 1-5.

EHLERs, E. 1864. Die Borstenwürmer (Annelida Chaetopoda) nach systematischen und anatomischen Untersuchungen. Leipzig. 1-268, 11 pls.

___ 1897. Polychaeten. In Ergebnisse der Hamburger Magalhaensischen Sammelreise. 3: $1-148$, pls. $1-9$.

1901. Die Polychaeten des magellanischen und chilenischen Strandes. In Festschrift zur

Feier des Hundertfunfzigjährigen Bestehens des K. Gesellschaft der Wissenschaften zu Göttingen. Berlin. 1-232, 25 pls.

Fauvel, P. 1923. Polychètes Errantes. Faune de France, 5: 1-488, 181 figs.

1932. Annelida Polychaeta of the Indian Museum, Calcutta. Mem. Indian Mus., 12: 1-262, 9 pls., 40 textfigs.

- 1934. Sur Quelques Syllidiens du Japon. Annot. Zool. Japon., 14: 301-315, 2 figs.

- 1936. Annélides Polychètes du Japon. Mem. Coll. Sci. Kyoto Univ., s. B, 12: 41-92, 1 fig.

1953. The Fauna of India including Pakistan, Ceylon, Burma and Malaya. Annelida Polychaeta. Allahabad. xii: 1-507, 250 figs.

Gidholm, L. 1962. Sur quelques polychètes Syllidiens des sables de la région de Roscoff avec description de deux nouvelles espèces. Cahiers de Biologie Marine, 3: 249-260, 1 pl., 3 figs. 
Grube, A.E. 1878. Annulata Semperiana. Beiträge zur Kenntniss der Annelidenfauna der Philippinen. Mém. Akad. Nauk SSSR, (7), 25 (8): i-ix, 1-300, 15 pls.

Hartman, O. 1944. New England Annelida. Pt. 2, including the unpublished plates by Verrill with reconstructed captions. Bull. Amer. Mus. Nat. Hist., 82 (7): 327-344, pls. 13-35, 45-60.

- 1945. The Marine Annelids of North Carolina. Bull. Duke Univ., Mar. Sta., 2: 1-54, 10 pls., 2 charts.

1948. The Polychactous Annelids of Alaska. Pac. Sci., 2: 1-58, 12 figs., 2 charts. 1953. Non-Pelagic Polychaeta of the Swedish Antarctic Expedition 1901-1903. In

Further Zool. Res. of the Swed. Antarctic Exped., 4 (11): 1-83, 21 figs.

- 1959. Catalogue of the Polychactous Annelids of the World. Pt. I, Allan Hancock

Found. Occas. Pap., 23: 1-353.

$1-226,34$ pls.

1961. Polychaetous Annelids from California. Allan Hancock Found. Pac. Exped., 25:

1964. Polychaeta Errantia of Antarctica. Antarctic research ser. 3: Amer. Geophysical Union, 1-131, 39 pls.

Hartmank-Sahröder, G. 1960. Polychaeten aus dem Roten Meer (Ergebnisse No. 8 der Reise von A. Remane und E. Schultz nach dem Roten Meer). Kieler Meeresforsch., 16: 69-125, 21 pls.

Haswell, W.A. 1885. Observations on some Australian Polychaeta. Proc. Linn. Soc. N.S. Wales, 10: 733-756, pls. 50-55.

1920. Australian Syllidae, Eusyllidae and Autolytidae. Ibid., 45: 90-112, pls. 10-13.

Horikosir, M. 1962. Distribution of Benthic Organism and Their Remains at the Entrance of Tokyo Bay, in Relation to Submarine Topography, Sediments and Hydrography. Nat. Sci. Rept. Ochanomizu Univ., 13 (2): 47-122, 62 figs.

Imajima, M. 1963. Polychaetous Annelids collected off the west coast of Kamchatka II. Notes on species found in the collection of 1959. Publ. Seto Mar. Biol. Lab., 11 (2): 345-372, 4 pls.

Imajima, M. and O. Hartman. 1964. The Polychaetous Annelids of Japan. Parts I, II. Allan Hancock Found. Occas. Pap., 26: 1-452, 36 pls.

IzukA, A. 1906. On a Case of Collateral Budding in Syllid Annelid (Trypanosyllis misakiensis n. sp.). Annot. Zool. Japon., 5: 283-287.

262, 24 pls.

1912. The Errantiate Polychaeta of Japan. Jour. Coll. Sci. Tokyo Univ., 30 (2): 1-

Johnson, H.P. 1901. The Polychaeta of the Puget Sound Region. Proc. Boston Soc. Nat. Hist., 29: $381-437,19$ pls.

LANGerhans, P. 1879. Die Wurmfauna von Madeira. Zeitschr. Wiss. Zool., 32: 513-592, pls. 31-33.

MaIntosh, W.C. 1885. Report on the Annelida Polychaeta collected by H.M.S. Challenger during the years 1873-76. Challenger Rpts., Zool., 12: 1-554, pls. 1-55, 1A-39A.

1908. A monograph of the British Annelids. Vol. 2, pt. 1. Polychaeta. Nephthyidae to Syllidae. (Ray Soc. Pub.) London. 1-232, pls. 43-50, 57-70.

Malmgren, A.J. 1867. Annulata Polychaeta Spetsbergiae, Grönlandiae, Islandiae et Scandinaviae hactenus cognita. Oefv. Svenska Vetensk. Akad. Forh., 24: 127-235, pls. 2-15.

Marenzeller, E.v. 1874. Zur Kenntniss der adriatischen Anneliden. Akad. Wiss. Wien, Sitzber., Abt. 1, 69: 407-482, pls. 1-7.

— 1879. Siidjapanische Anneliden. I. Denkschr. Akad. Wiss. Wien, Math.-Naturwiss. Kl., 41 (2): 109-154, pls. 1-6.

___ 1890. Annulaten des Beringmeeres. K. Naturhist. Hofmus. Wien, Ann., 5: 1-18, 1 pl. 1892. Zoologische Ergebnisse der im Jahre 1889 auf Kosten der Bremer Geographischen Gesellschaft von Dr. Willy Kükenthal und Dr. Alfred Walter ausgeführten Expedition nach Ostspitzbergen. Polychäten. Zool. Jahrb., Abt. Syst., 6: 397-434, pl. 19.

Marion, A.F. 1879. Draguages au large de Marseille. Ann. Sci. Nat. Paris, ser. 6, 8: 1-48, 4 pls.

Michel, A. 1909. Sur les divers types de stolons chez les Syllidiens, spécialement sur une nouvelle espèce (Syllis cirropunctata $\mathrm{n}$. sp.) á stélons acéphale et sur la réobservation du stolone tétracére de Syllis amica Qfg. Acad. Sci Paris, C.R., 148: 318-320. 
Munxu, U. 1950. Polychaeta Worms. In Great britan. Discovery Rpts., 2: 1-222, 91 figs.

1934. On a collection of Polychaeta trom the coast of China. Ann. Mag. Nat. Hist. London, ser. 10, 13: 353-380, 10 figs.

321, 28 figs.

1937. Polychaeta. In Sci. Rpts. of the John Murray Expedition 1933-34. 4 (8): 243-

1939. On some tropical Polychaeta in the British Museum, mostly collected by Dr. C. Crossland at Zanzibar, Tahiti and the Marquesas. (II. families Syllidae and Hesionidae). Novitat. Zool. London, 41: 383-393, 4 figs.

Moore, J.P. 1908. Some Polychaetous Annelids of the Northern Pacific Coast of North America. Proc. Acad. Nat. Sci. Phila., 60: 321-364.

Nishimura, S. 1964. Considerations on the migration of the leatherback turtle, Dermochelys coriacea (L.), in the Japanese and adjacent waters. Publ. Seto Mar. Biol. Lab., 12 (2): 177-189, 3 textfigs.

OKada, Yö K. 1933. Two interesting Syllids, with Remarks on their asexual Reproduction. Mem. Coll. Sci., Kyoto Univ., (B) 8: 325-338, pl. 12, 11 figs.

1933. Syllidian Miscellany. Mar. Biol. Ass. U.K., Jour., 18: 641-653, 6 figs.

1934. Amblyosyllis nigrolineata, une nouvelle variété de l'A. speciosa Izuka. Annot. Zool.

Japon., 14 (3): 317-320, 2 figs.

Okuda, S. 1937. Polychaetous Annelids from the Palau Islands and Adjacent Waters, the South Sea Islands. Bull. Biogeogr. Soc. Japan, 7 (12): 257-315, 59 figs.

1938. Polychaetous Annelids from the Vicinity of the Mitsui Institute of Marine Biology.

Japan. Jour. Zool., 8: 75-105, 15 figs.

Okuda, S. and M. Yamada 1954. Polychaetous Annelids from Matsushima Bay. Jour. Fac. Sci. Hokkaido Univ., ser. 6, Zool., 12: 175-199, fig. 1-10.

Pettibone, M.H. 1954. Marine Polychaete Worms from Point Barrow, Alaska, with Additional Records from the North Atlantic and North Pacific. Proc. U.S. Natl. Mus., 103: 203-356, figs. 26-39.

1956. Some polychaete worms of the families Hesionidae, Syllidae, and Nereidae from the east coast of North America, West Indies, and Gulf of Mexico. Jour Washington Acad. Sci., 46 (9): 281-294, 8 figs.

1963. Marine Polychaete Worms of the New England Region. 1. Aphroditidac through Trochochaetidae. Bull. U.S. Nat. Mus., 227: 1-356, 83 figs.

Rioja, E. 1925. Anelidos poliquetos de San Vicente da la Barquera (Cantabrico). Mus. Naccien. Nat. Madrid, Trab., 53: 1-62.

1943. Estudios Anelidologicos, VII. Aportaciones al Conocimiento de los Exogoninos (Anel. Poliquetos) de las Costas Mexicanas del Pacifico. An. Inst. Biol. Mexico, 14: 207-227, figs. $1-47$.

Rullier, F. 1963. Les Annélides Polychaètes du Bosphore, de la Mer de Marmara et de la Mer Noire, en relation avec celles de la Méditerranée. C.I.E.S.M.M., 17 (2): 161-260.

Saint-Joseph, B.A.de. 1887. Les Annélides polychètes des côtes de Dinard. Ann. Sci. Nat. Paris, ser. 7 (1): 127-270, pls. 7-12.

Thorson, G. 1946. Reproduction and larval development of Danish marine bottom invertebrates, with special reference to the planktonic larvae in the Sound ( $\Phi$ resund). Medd. Komm. Danmarks Fish. Havunders $\phi$ gelser. Ser.: Plankton, 4 (1): 1-523, 199 figs.

Uschakov, P. 1950, Mnogoshchetinkovye chervi (Polychaeta) Okhotskogo Moria. Akad. Nauk SSSR., Zool. Inst., Issled. dal'nevost. moreì SSSR. 2: 140-237, 2 pls., 39 figs.

1955. Mnogoshchetinkovye chervi dal'nevostochunykh Morě SSSR (Polychaeta). Akad.

Nauk SSSR, Zool. Inst,, Opredeliteli po Faune SSSR, 56: 1-445, 164 figs.

Uschakov, P. and B.L. Wu 1962. The Polychaetous Annelids of the Fam. Syllidae, Hesionidae, Pilargiidae, Amphinomidae, Eunicidae from the Yellow Sea. (In Chinese and Russian) Studia Marina Sinica, 1 (1): $57-85,3$ pls. 
Utinomi, H. 1956. Un the so-called "Umi-Utiwa", a peculiar Flabellate Gorgonacean, with Notes on a Syllidean Polychaete Commensal. Publ. Seto Mar. Biol. Lab., 5: 243-250, pl. 27, 2 text-figs.

VerriLL, A.E. 1874. Notice of the Remarkable Marine Fauna Occupying the Outer Banks off the Southern Coast of New England. Amer. Jour. Sci. 7: 131-138.

1885. Notice of recent additions to the marine Invertebrata of the northeastern coast of America, with descriptions of new genera and species and critical remarks on others. Proc. U.S. Nat. Mus., 8: 424-448.

1900. Additions to the Turbellaria, Nemertina and Annelida of the Bermudas, with revisions of some New England genera and species. Conn. Acad. Arts Sci., Trans., 10: 595-671, $1 \mathrm{pl}$.

Webster, H.E. 1879. Annelida Chaetopoda of the Virginian coast. Albany Inst. N.Y., Trans., 9: 202-269, 11 pls.

Wesenberg-Lund, E. 1947. Syllidae (Polychaeta) from Greenland Waters. Danmark, Medd. om Gronland, 134 (6): 1-38, 15 figs.

- 1962. Polychaeta Errantia. In Rpts. of the Lund Univ. Chile Expedition 1948-49. 43. Arsskr. Lunds Univ., N.F., Avd. 2, 57 (12): 1-139, 49 figs.

Winternitz, J.K. 1936. New species of polychaetous annelids collected at Appalachicola, Florida, by Dr. A.S. Pearse, in 1935. Amer. Mus. Nov. N.Y., 888: 1-3, 12 figs. 